\title{
Geografski pogledi na strokovne planerske analize
}

\author{
Andrej Černe \\ Dr., Oddelek za geografijo, Filozofska fakulteta, Univerza v Ljubljani, \\ Aškerčeva 2, 1000 Ljubljana, Slovenija \\ e-mail: andrej.cerne@guest.arnes.si
}

\section{Izvleček}

Prispevek obravnava z geografskega vidika nekatera vprašanja opredeljevanja tako imenovanih strokovnih podlag pri pripravi prostorskih planskih dokumentov. Poudarek je na pripravi analize stanja in na opredeljevanju prostorskih problemov.

Ključne besede: planiranje, analiza stanja, prostorski problemi, geografski vidiki

\section{Geographical Aspects of Proffesional Planning Expertise}

\begin{abstract}
The article deals with the geographical aspect of several questions for determing the so called professional expertise for the preparation of spatial planning documents. The emphasis is on the analysis of spatial conditions and problems of spatial development.
\end{abstract}

Key words: planning, analysis of spatial conditions, problems of spatial development, geographical aspects 


\section{ANALIZA}

$\mathrm{V}$ dosedanjem postopku priprave tako imenovanih prostorskih sestavin je bila analiza namenjena pripravi strokovnih podlag. V Zakonu o urejanju prostora (UL SRS, št. 18, junij 1984) je bilo v poglavju o planiranju v prostoru posvečena posebna pozornost strokovnim podlagam in evidencam, ki so bile namenjene pripravi prostorskih sestavin planskih aktov. Njihova vsebina je bila podrobneje opredeljena $\mathrm{v}$ Navodilih o vsebini in metodologiji izdelave strokovnih podlag in prostorskih sestavin planskih aktov občin, $\mathrm{v}$ katerem so bila $\mathrm{v}$ posebnem podpoglavju podana splošna navodila za pripravo strokovnih podlag. Strokovne podlage za pripravo prostorskih sestavin dolgoročnih in srednjeročnih planov so bile posebej opredeljene v podpoglavju o Analizi možnosti dolgoročnega družbenega razvoja in v 22. členu strokovnih podlag za srednjeročne družbene plane občin ter v podpoglavju o Analizi možnosti srednjeročnega razvoja. Po teh navodilih in določilih so se prostorske sestavine analize možnosti dolgoročnega družbenega razvoja (AMDR) nanašale na:

- analizo dosedanjega razvoja, stanja in razvojnih teženj;

- predlog zasnov dolgoročnega razvoja v prostoru;

- strokovna izhodišča za oblikovanje prostorskih sestavin smernic.

Analiza je bila namenjena proučitvi ključnih problemov urejanja prostora, ki izhajajo iz obstoječega stanja, predvidenega nadaljevanja dosedanjih razvojnih teženj ter iz medsebojnih neskladij pri že sprejetih tako imenovanih planskih odločitvah. Pri tem je bil poudarek na:

- položaju oziroma vlogi občine in mest ter drugih pomembnejših naselij v razmerju do sosednjih občin oziroma celotne Slovenije;

- značilnosti poselitve in organizacije dejavnosti na območju občine;

- značilnosti prostora in možnosti za spreminjanje namenske rabe.

Položaj oziroma vloga občine in mest ter drugih pomembnejših naselij v razmerju do sosednjih občin oziroma celotne Slovenije je obsegal analize:

- stopnje centralnosti, prometne vloge, proizvodne in upravne vloge občinskega središča in drugih naselij, ki presegajo občinski pomen;

- globalne analize in projekcije prebivalstva in delovnih mest $\mathrm{v}$ občini in njihovega deleža v širšem območju ter v Sloveniji kot celoti;

- razpoložljivosti naravnih virov v občini ter pogojev za njihovo racionalno rabo, ob upoštevanju varovanja okolja in tako imenovanih dobrin splošnega pomena. 
Značilnosti poselitve in organizacije dejavnosti na območju občine so bile opredeljene na področju:

- prebivalstva: selitvenih gibanj predvsem v povezavi s praznjenjem območij; pretirano koncentracijo prebivalstva in $\mathrm{v}$ povezavi s procesom deagrarizacije;

- delovnih mest: razmestitve, dosedanjega procesa koncentracije oziroma disperzije, dostopnosti in oddaljenosti delovnih mest od kraja bivanja;

- predvidevanj o bodočem številu ter sestavi prebivalstva in delovnih mest $\mathrm{v}$ občini in njenih delih, ki so bila opredeljena na podlagi analitičnih ocen demografskih projekcij, socialnoekonomskih predvidevanjih o razvojnih možnostih in potrebah ter na podlagi ciljev razvojne politike v občini. Pri tem so bila upoštevana predvidljiva migracijska gibanja na ravni občine, in sicer v okviru demografskih projekcij v analizah možnosti dolgoročnega razvoja za širša območja oziroma za celo Slovenijo.

Značilnosti prostora in možnosti za spreminjanje namenske rabe je bila opredeljena na podlagi analiz o obremenitvi okolja in ogroženosti prostora, primernosti prostora, ranljivosti prostora in ustreznosti prostora.

Obremenitev okolja in ogroženost prostora se je nanašala na:

- $\quad$ splošne značilnosti ekološkega stanja v prostoru;

- vire onesnaževanja okolja;

- območja večje onesnaženosti in območja potrebnih sanacij;

- posledic nadaljevanja onesnaževanja za bivanje in delovne pogoje in posamezna območja;

- območja, ki so ogrožena zaradi naravnih pojavov ali procesov, ali zaradi človekovih dejavnosti in posegov v prostor, ali zaradi morebitne vojne.

Primernost prostora je bila namenjena:

- opredeljevanju namenske rabe prostora;

- določanju meril za ugotavljanje primernosti za posamezno namensko rabo;

- ugotovitev razmer v prostoru;

- opredeljevanju večje ali manjše primernosti za posamezno bodočo namensko rabo.

Ranljivost prostora je bila izražena $\mathrm{v}$ obliki možnih negativnih vplivov predvidene dejavnosti na naravne in ustvarjene vrednote okolja. Pri določanju stopnje ranljivosti so bili upoštevani pogoji, ki izhajajo iz naravnih značilnosti, iz dosedanje namenske rabe, obremenitve okolja in ogroženosti prostora ter iz normativov in standardov dopustnih obremenitev okolja.

Ustreznost prostora pa je bila rezultat soočenja primernosti in ranljivosti prostora, ki naj bi odražala strokovno uskladitev med varovalnimi in razvojnimi interesi v prostoru. 
Analize so torej razmeroma zahtevne tako po teoretski kot po metodološki in vsebinski plati, saj pokrivajo številna področja, poleg tega pa morajo biti tudi ciljno usmerjene. $\mathrm{V}$ širšem smislu so namenjene razumevanju sedanjih razmer, opredeljevanju ciljev razvoja, oblikovanju splošnih načel za usmerjanje nadaljnjega razvoja in oblikovanju konceptov razvoja ter sprejemanju odločitev. V prvi vrsti se nanašajo na pogoje, potenciale in omejitve ter posamezne razvojne kategorije, oblike, funkcije in strukture. Hkrati pa se nanašajo tudi na splošne družbene, gospodarske, socialne, institucionalne in pravno formalne razmere ter tehnično-tehnološke možnosti. Analize različnih regionalnih, prostorskih, družbenih, gospodarskih in institucionalnih ter ostalih pogojev se nanašajo ne nazadnje tudi na gospodarski razvoj (sistem zasebnega podjetništva in sodobnega konkurenčnega tržišča), družbeno pravičnost in varstvo okolja $\mathrm{v}$ kontekstu tržne in družbene racionalnosti oziroma učinkovitosti, ki brezpogojno upošteva človeške in okoljske stroške gospodarske rasti.

Poleg tega pa se $\mathrm{z}$ analizami soočamo tudi s temeljnimi vsebinami opredeljevanja prihodnjega razvoja:

- $\quad \mathrm{z}$ dejstvi, ki opisujejo obstoječe stanje in prihodnje pogoje (razmere) ter dejavnike, ki vplivajo na nastajanje razvojnih problemov;

- $\quad$ z razvojnimi problemi in prioritetami za njihovo reševanje;

- $\quad$ s temeljnimi načeli in izhodišči za usmerjanje razvoja;

- $\quad$ z opredeljevanjem možnih rešitev ter izvajanjem ukrepov.

Analize so relevantne torej gleda na načela in cilje razvoja, glede na dejavnike, ki vplivajo na razvojne probleme in glede na izvedljivost ali učinkovitost možnih potencialnih rešitev.

Analize so torej eno izmed pomembnih strokovnih gradiv pri pripravi razvojnih konceptov, in sicer znotraj konteksta racionalnega planerskega modela, ki vsebuje predvsem naslednje postopke:

- opredeljevanje namenov in ciljev;

- zasnova alternativ za doseganje ciljev;

- vrednotenje posledic;

- izbor prednostnih alternativ;

- izdelava plana;

- implementacija;

- monitoring;

- revizija plana.

Stopnje in različne strokovne naloge pri pripravi planov niso ločene in nepovezane. Naloge so v določeni soodvisnosti in proces vsebuje številne povratne vplive. Analize potekajo sočasno s pripravo razvojnega koncepta. Pri pripravi analize opisujemo pravzaprav proces, ki poskuša združevati različne strokovne analize s planom. Čeprav so analize izrednega pomena za sam proces priprave 
plana, in lahko tudi podajajo večino razlag za nadaljnji razvoj, pa vendarle ne nakazujejo poti za njihovo reševanje, saj je to namen samega plana. Analize sodijo torej $\mathrm{v}$ analitični del priprav strokovnih gradiv. Tvorijo eno izmed faz cikličnega pristopa (za razliko od linearnega) v planiranju, ki temelji na sprotnem preverjanju rezultatov strokovnega dela in njihovemu nadaljnjemu vključevanju v pripravo skupnih enovitih strokovnih podlag.

Analize so predpogoj za razmišljanja o sprejemanju odločitev o oblikovni, funkcijski in strukturni zasnovi razvoja oziroma o razmerjih med posameznimi kategorijami in funkcijami (npr. razmerjih med urbanimi, suburbanimi in podeželskimi območji oziroma razmerja med urbanim območji in podeželjem). Ne nazadnje nam omogočajo tudi iskanje odgovorov na vprašanja, ali je potrebno spreminjati obstoječe regionalne razmere oziroma ustvarjati drugačne pogoje in razmere $\mathrm{v}$ katerih bo potekal regionalni razvoj. Spreminjanje pogojev, njihovo izboljšanje, oziroma saniranje in preprečevanje vzrokov za nastajanje nezaželenih razmer in s tem ustvarjanje novih pogojev in potencialov pa zahteva dobro poznavanje obstoječih in predvidenih pogojev razvoja.

Čeprav velikokrat razpravljamo najprej o dejstvih pred opredeljevanjem ciljev, pa potekajo naloge vedno sočasno. Analize razodevajo in se nanašajo na razvojne probleme in s tem na nek način tvorijo informacije za opredeljevanje ciljev. Opredeljevanje vprašanj razvoja, vrednot in prioritet pa istočasno pomaga opredeljevati katera dejstva in problemi so relevantni. Analiza prispeva k spoznavanju in razumevanju stanja in razmer na več načinov. Prvič, jasna slika o stanju pomaga pri opredeljevanju vprašanj, ciljev in prioritet. Drugič, dobra analiza prispeva $\mathrm{k}$ iskanju dobrih rešitev. Tretjič, dobra analitična podlaga pomaga pri utemeljevanju in obrazložitvi.

Analize se seveda razlikujejo tudi glede drugih razsežnosti. Nekatere analize se nanašajo na pretekle in sedanje pogoje. Druge so projekcije bodočih pogojev. Nekatere analize izhajajo iz znanstvenih raziskav in znanj, nekatere izhajajo iz vsakdanjega vedenja in iz osebnih izkušenj, opazovanj ali raznih razprav.

Pozornost analize je usmerjena na dejstva o sedanjih razmerah, težnjah in možnih prihodnjih pogojih. $V$ strateškem planiranju se ta dejavnost nanaša na pretresanje razmer in spoznavanje ključnih razvojnih dejavnikov. Predvidevanja oziroma napovedovanja pa se nanašajo v prvi vrsti na dejavnike in pogoje, ki so več ali manj predvidljivi in jih lahko ocenimo s tehnikami projekcij, kot so razmerja, ekstrapolacija in simulacija.

Najpogosteje se analize nanašajo na analizo:

- obstoječega stanja in razvojnih teženj;

- problemov dosedanjega razvoja;

- temeljnih predpostavk o prihodnjem razvoju;

- možnih posledic prihodnjega razvoja; 
- doseganja splošnih in posebnih ciljev razvoja;

- znanih in predvidenih pogojev, potencialov in omejitev za prihodnji razvoj.

Namenjene pa so spoznavanju naslednjih elementov:

- doseganju ciljev razvoja;

- reševanju ključnih razvojnih problemov;

- odpravljanju nezaželenih pojavov in procesov;

- odpravljanju nezaželenih posledic razvoja;

- razvojnih omejitev;

- prihodnjih pogojev razvoja.

Brez upoštevanja temeljnih načel in ciljev razvoja pomenijo analize, več ali manj opis »obstoječih ali predvidenih pogojev«, in sicer brez kakršnega koli stališča o tem, zakaj so ti pogoji oziroma razmere pomembne. Temeljna načela se nanašajo na suverenost odločanja, trajnostni, sonaravni in endogeni razvoj, splošne družbene vrednote, decentralizacijo in participacijo pod enakimi pogoji na različnih ravneh odločanja, znanstveni in strokovni pristop ter na spoštovanje mednarodnih meddržavnih ter regionalnih pogodb in dogovorov. Splošni cilji pa so naravnani na izboljšanje kakovosti življenja in fizičnega okolja, zagotavljanje trajnostnega razvoja in razvojnih priložnosti in pogojev za vse prebivalce. Zato moramo analize obravnavati v kontekstu objektivnih meril, stanja, načel in ciljev razvoja in znotraj konteksta ciljev regionalnega in prostorskega razvoja, ki niso nič več in nič manj kot raznolik, relativno stabilen dobro uravnotežen in trajen razvoj, ki lahko zadovoljuje zahteve/potrebe vsakega habitata.

Pristop k analizam razmer mora poteka torej znotraj konteksta jasnih meril vrednotenja, ki se nanašajo predvsem na:

- ekonomske koristi: ekonomska učinkovitost se nanaša na koordinacijo javnega in zasebnega razvoja $\mathrm{v}$ tem smislu, da so potovanja iz kraja bivanja v kraj zaposlitve, iz kraja bivanja do šole, iz kraja bivanja do rekreacijskih območij, iz kraja bivanja ali kraja zaposlitve do storitvenih dejavnosti čim krajša; da ima industrija dober dostop do regionalnega prometnega omrežja; da omogoča prostorska razporeditev rabe zemljišč kar najlažjo oskrbo s pitno vodo, komunalnim sistemom, prometom in ostalimi storitvami; da so javne in zasebne dejavnosti energetsko učinkovite; regionalna strukturo naj temelji na taki organizaciji rabe zemljišč, ki je ekonomična za skupnost, storitve in tudi za uporabnike zemljišč;

- varovanje zakonitosti: gospodarjenje z zemljišči mora spoštovati zakonite cilje; gre za izogibanje prisvajanja lastnine brez prave kompenzacije, upoštevanje različnih interesov in prebivalcev $\mathrm{v}$ regij; enako in pošteno obračanje na vse ljudi v podobnih okoliščinah in ne diskriminiranje različnih skupin prebivalstva; 
- možnost izbire: gre za zagotavljanje različnih vrst prostora, gostot, lokacij in tipov razvoja zaradi tega, da lahko prebivalci izbirajo kraje glede na njihov okus in žep;

- kakovost okolja: kakovost okolja se nanaša na kakovost zraka, vode in zemljišč ter ustvarjenega okolja;

- kakovost življenja: kakovost življenja je cilj, ki izraža neekonomske, manj jasne in manj kvantificirane kategorije blaginje skupnosti oziroma splošne blaginje skupnosti;

- zdravje in varnost: zdravje in varnost se nanašata na nevarnosti za zdravje in pojavljanje poškodb in na promocijo fizične in emocionalne blaginje;

- učinkovitost ter izvedljivost: učinkovitost in izvedljivost sta cilja, ki se nanašata na razvojna merila. Učinkovitost se nanaša na možnosti doseganja ciljev. Preprost test je v tem, ali razvojni predlogi res opravljajo tisto za kar so bili predvideni. Ali raba zemljišč dosega cilje, ki jih zasleduje prostorska zasnova? Ali sistem dosega zaželeni vzorec rabe zemljišč? Ali strategija izvajanja dosega cilje sprejetega plana?

- prostorske spremembe: planer mora opredeliti demografske in gospodarske spremembe, ki določajo »potrebe« po zemljiščih, stanovanjih, vodi, prometu, šolah, rekreacijskih zmogljivostih, čiščenju pitne vode, odlaganju odpadkov in drugih komunalnih storitvah. Spreminjanje rasti in sprememb v potrebah pomeni uporabljanje standardov, ki so na začetku lahko $\mathrm{v}$ obliki opcij, kasneje pa so lahko ocenjeni in izbrani v procesu opredeljevanja želja, interesov in razvojnih možnosti. Gre za spreminjanje projekcij v zahteve po prostoru in zahteve po opremljenosti prostora.

Pri analizah stanja in razmer se soočamo torej z razmeroma pestro paleto metodoloških in vsebinskih vprašanj ter veliko stopnjo zahtevnosti po oblikovanju jasnih strokovnih izhodišč. Načini spoznavanja stanja oziroma razmer so številni, raznovrstni in kompleksni. Ravno zaradi tega bi veljalo zasnovati analize predvsem na podlagi:

- selektivnega pristopa;

- opredeljevanja prioritet;

- opredeljevanja ciljev za reševanje razvojnih problemov;

- zasnove strategij za doseganje ciljev.

\section{PROSTORSKI PROBLEMI}

Pri prostorskih problemih se soočamo vsaj s petimi pomembnimi stopnjami njihovega opredeljevanja:

- določanjem konteksta za opredeljevanje;

- samim opredeljevanjem; 
- analizo;

- reševanjem;

- rezultati reševanja problemov.

Soočeni smo z velikim številom prostorskih problemov, ki kažejo razmeroma veliko pestrost tako glede samih pojavnih oblik (procesi, pojavi, stanja), kot glede samih regionalnih in prostorskih razsežnosti. Različni prostorski problemi so opredeljeni na različnih prostorskih ravneh, nekateri so opredeljeni tudi $\mathrm{z}$ vidika možnih prihodnjih, predvsem negativnih posledic za nadaljnji razvoj, in sicer v prvi vrsti na okolje in kakovost prostorskih in s tem življenjskih in bivalnih razmer.

Obstaja torej velika raznolikost oziroma raznovrstnost in kompleksnost regionalnih problemov. Rittel in Webber $(1973,1983)$ govorita celo o tako imenovanih »zlobnih" problemih planiranja. Raznolikost/raznovrstnost in kompleksnost je seveda lahko zelo obsežna, v kolikor poskušamo opredeljevati prostorske probleme na podlagi različnih vidikov, saj so po definiciji "vsi vidiki" prostorskih problemov lahko zelo številni. Pozornost je namreč lahko usmerjena na zelo različna vsebinska področja. Ali so razlike med regijami glede gibanja in gostote prebivalstva, višine bruto domačega proizvoda, strukture zaposlenih in različne stopnje onesnaženosti okolja že regionalni problem oziroma prostorski problem regije? Prostorske probleme lahko opredeljujemo torej na zelo različne možne načine oziroma $\mathrm{z}$ zelo različnih zornih kotov. Načini, kako so problemi opredeljeni lahko usmerjajo našo pozornost samo na nekatere, posamezne vidike ali posamezne dejavnike oziroma elemente teh problemov. To lahko seveda povzroča zanemarjanje ali celo negiranje ostalih pomembnih vidikov, lastnosti in značilnosti prostorskih problemov. Nekatere lastnosti in značilnosti so lahko nepoznane in neproučene, ali pa jih preprosto ne poznamo, in jih ravno zaradi tega ne upoštevamo in ne obravnavamo. Težava je tudi v tem, ker je značaj regionalnih problemov izredno kompleksen, saj je število spremenljivk lahko zelo veliko, le-te pa so med seboj najpogosteje $\mathrm{v}$ razmeroma zelo tesni medsebojni povezanosti in soodvisnosti. Le malo je takih regionalnih problemov, ki jih lahko ločimo in reduciramo na omejeno število spremenljivk in medsebojnih razmerij, ki bi imela samo enorazsežnostni vrednostni sistem.

Opredeljevanje prostorskih problemov temelji predvsem na dveh možnih pristopih. V obliki deskriptivnega pristopa oziroma modela, ki poskuša opredeljevati regionalne probleme na podlagi različnih možnih vidikov: strokovnega, tehničnega, političnega, uradniško-administrativnega, zakonskega, sektorskega, itd. Vsak vidik ima seveda lastno opredelitev prostorskega problema, in kakšne so njegove značilnosti. Nekateri ocenjuje npr. prostorsko razpršenost v dolgoročnem razvoju naših mest, suburbanih območij ali ruralne krajine kot negativni pojav. Suburbanizacija je tako pogosto povezana z nastajanjem 
črnih gradenj. Drugi pa menijo, da je suburbija idealna in logična oblika poseljenosti v današnjem času.

Posebno vprašanje predstavljata dva problemska sklopa, v katerih se medsebojno prepletajo gozdarstvo, kmetijstvo, vodno gospodarstvo in poselitev. To sta zaraščanje za obdelovanje manj primernih kmetijskih zemljišč predvsem v hribovitih območjih (prostorsko širjenje gozdov) ter krčenje območij gozdov, ostankov gozda pa tudi gozdnega rastja zunaj gozda (predvsem izginjanje manjših vegetacijskih sestojev - skupin dreves in grmovnic, omejkov, posameznih dreves ali grmovnic, obvodnega rastja predvsem v ravninskem, kmetijskem svetu in na območju obvodnega prostora). Pri zaraščanju je težava predvsem $\mathrm{v}$ poseganju na kmetijski prostor in povečevanju gozda na račun kmetijskega prostora. Razmerja med kmetijskimi in gozdnimi zemljišči se v različnih območjih precej razlikuje. Tako je npr. v Prekmurju ta delež približno 1:5 v korist njivskih površin, na Kočevskem pa, nasprotno, približno 1:10 v korist gozda. Zato so različni tudi prostorsko problemi: medtem ko na Kočevskem tečejo prizadevanja za ureditev zaraščanja opuščenih kmetijskih zemljišč, se v Prekmurju poskuša uveljaviti ohranjanje naravne zarasti v prevladujočem kmetijskem prostoru. Pri krčenju majhnih gozdnih zaplat pa so lahko nasprotja tudi znotraj ene dejavnosti (tradicionalen ali intenziven način kmetovanja) ali pa nastajajo med različnimi dejavnostmi (kmetijstvo, gozdarstvo, poselitev, urejanje voda). Dodaten vzrok za zaraščanje negozdnih površin in neohranjanje manjših gozdnih sestojev je tudi spreminjanje tehnologije dela in opuščanje predvsem številnih dopolnilnih dejavnosti (pletenje košar ipd.). To so območja, na katerem prihaja do prepletanja različnih funkcij in rab ter s tem tudi do ustvarjanja spornih stanj (Černe, 2002).

Za razliko od tega pristopa je normativni pristop namenjen opredeljevanju prostorskih problemov znotraj določenega konteksta in koncepta, npr. $\mathrm{z}$ vidika smotrnosti (teleološki vidik) ali z vidika strokovnih načel, kodeksov, norm oziroma strokovne etike (Hendler, 1990). Pri prvem vidiku so opredelitve in rešitve prostorskih problemov ocenjene glede na možne posledice oziroma vrednotenje teh posledic, pri drugem vidiku pa so ocene narejena na podlagi deontološkega vrednotenja.

Načinov oziroma metod s katerimi lahko opredeljujemo prostorske probleme je torej zelo veliko. Zato obstajajo tudi številne možne razlage. Glede na različne možne razlage pa so možne seveda tudi zelo različne rešitve. To pa pomeni, da smo soočeni s številnimi možnimi rešitvami. Le-te pa so odvisne v prvi vrsti od možnih ciljev reševanja regionalnih problemov. Med drugim tudi od tega ali želimo te probleme:

- odpraviti, na ta način, da poskušamo vplivati na tiste vzroke, ki povzročajo njihovo nastajanje;

- preusmerjati v zaželene in možne oblike, funkcije in strukture; 
- omiliti oziroma zmanjšati njihov prostorski obseg, intenzivnost, čas trajanja;

- spremeniti njihov relativni pomen oziroma težo v vse splošnih razvojnih težnjah;

- upočasniti nekatere njihove nezaželene procese;

- odpravljati njihove negativne vplive oziroma posledice;

- spremeniti njihove nezaželene pojavne oblike itd.

$\mathrm{Na}$ vse omenjene možne predloge za reševanje regionalnih problemov bi seveda lahko odgovorili $\mathrm{z}$ da. Vendar $\mathrm{s}$ tem še nismo odgovorili na temeljno vprašanje, zakaj jih želimo rešiti? Zato, ker nam povzročajo ekološke, okoljske, ekonomske, prostorske, pravno-formalne, tehnične, finančne in ostale probleme? Ali preprosto zato, ker so to problemi, ki onemogočajo doseganje oblikovnih, funkcijskih in strukturnih pestrosti prostora kot temeljnega elementa boljših pogojev življenja in bivanja? To govori v prid tezi, da prostorski problemi niso v prvi vrsti vprašanja »discipline«, marveč vprašanja usmerjanja, spreminjanja, posameznih pojavov in procesov oziroma razvojnih teženj $\mathrm{v}$ skladu z možnimi cilji prihodnjega razvoja, in ne nazadnje vprašanj izboljšanja pogojev življenja in bivanja. V kolikor soglašamo, da je pojav degradiranih urbanih območij v slovenskih mestih eden izmed razvojnih problemov, in da je cilj reševanja tega problema regeneracija, revitalizacija teh območij, se moramo soočiti še z vprašanjem glede različnih možnih načinov reševanja tega problema. Lahko gre seveda za pragmatično, inkrementalno iskanje rešitev, ki je učinkovita in bo vodila k primernim, ustreznim rezultatom.

Soočeni smo torej s vprašanjem, ali za reševanje prostorskih problemov ponuditi (zasnovati) jasna načela, izhodišča in cilje na podlagi katerih bo možno nedvoumno prepoznavanje prostorskih problemov in sprejemanje ustreznih odločitev za rešitve v skladu z dolgoročnimi cilji razvoja. (Faludi, 1996)

Stvari so lahko razmeroma enostavne, v kolikor imamo jasna stališča o tem, kaj so regionalni problemi, kakšen je njihov značaj in kakšen je njihov pomen ter o tem, kaj želimo narediti s problemi, in ne nazadnje seveda tudi o tem, kako to narediti. $Z$ večjimi težavami se lahko soočamo v primerih, ko nimamo izoblikovanih jasnih stališč glede omenjenih vprašanj, vemo pa, kako bi se lotili alternativ. V najslabšem položaju se lahko znajdemo takrat, ko nimamo na voljo niti enotnih stališč, niti ne vemo, kako bi se lotiti stvari.

$\mathrm{Ne}$ obstaja torej samo ena pravilna razlaga ali ena sama rešitev za prostorske probleme. Lahko bi celo rekli, da za prostorske probleme na splošno ne obstajajo prave ali napačne rešitve. Rešitve so samo dobre ali slabe, relativno glede druga na drugo in relativno glede na vrednostni sistem znotraj katerega jih rešujemo. Vrednostni sistemi družbe in posameznikov pa opredeljujejo načine gledanja na regionalne problem oziroma njihovo reševanje. Čeprav so seveda konflikti med različnimi interesi na različnih področjih in različnih 
območjih ter prostorskih ravneh vedno neizbežni že pri samem opredeljevanju regionalnih problemov, še bolj pa pri iskanju in sprejemanju odločitev o njihovem reševanju.

Regionalni problemi se razlikujejo torej med seboj po številnih nejasnostih, ki se nanašajo na različne možne načine za njihovo opredeljevanje in njihovo reševanje in ne nazadnje na možne končne rezultate. Nezanesljivost je temeljna značilnost vseh regionalnih problemov (Christensen, 1985). Zato bi veljalo postaviti jasne okvirje, kot nek stabilen element, na katerega se lahko opremo pri opredeljevanju, obravnavanju in reševanju regionalnih problemov.

Verjetno je najprimernejši začetek za opredeljevanje in reševanje kompleksnega značaja prostorskih problemov vsekakor jasen kontekst znotraj katerega opredeljujemo in rešujemo te probleme. Številni zastopajo mnenje, da se mora planiranje nanašati v bistvu na konceptualne okvirje, ki omogočajo urejanje kompleksnosti (Chadwick, 1971). S tega vidika bi lahko gledali na prostorsko planiranje kot na dejavnost, ki uporablja določene pristope za reševanje problemov stvarnega sveta.

Številni možni načini opredeljevanja in številni možni načini reševanja regionalnih problemov lahko ne nazadnje vodijo tudi v različne možne rezultate. Dejstvo pa je, da je izredno težko spoznati, kdaj so prostorski problemi rešeni. Rešitve zahtevajo namreč neprestano spremljanje. In verjetno obstajajo vedno določene možnosti za izboljšanje predlaganih rešitev. Potem, ko smo poiskali rešitev za prostorske probleme, se ne moremo več vračati nazaj na prvotno stanje, v katerem smo te rešitve oblikovali (Černe, 1999).

\section{Literatura:}

Chadwick, G. (1971) A Systems View of Planning. Pergamon, Oxford.

Christensen, K. S. (1985) Coping with Unceratinty in Planning. Journal of the American Planning Association, Vol. 51, No, 1, str. 63-73.

Černe, A. (2002) Analiza stanja in trendov prostorskega razvoja Republike Slovenije. Raziskovalna naloga, Ministrstvo za okolje in prostor, Urad republike Slovenije za prostorsko planiranje, Ljubljana.

Černe, A. (1999) Questions of Regional Development in Slovenia (Vprašanja regionalnega razvoja Slovenije). Razvojne možnosti Slovenije, Bodočnost mest, 80. letnica Oddelka za geografijo, Dela 14, Oddelek za geografijo, Filozofska fakulteta, Univerza v Ljubljani, Ljubljana, str. 137-150.

Hendler, S. (1990) Professional Codes as Bridges Between Planning and Ethics: A Case Study. Plan Canada, Vol. 30, No. 2, str. 22-29. 
Faludi, A. (1996) Rationality, Critical Rationalism and Planning Doctrine. Explorations in Planning Theory, Ed. S. J. Mandelbaum, 1. Mazza, R. W. Burchell, Center for Urban Policy Research, Rutgers, New Jersey, str. 65-82.

Rittel, H. W. J., Webber, M. M. (1973) Dilemmas in a General Theory of Planning. Policy Sciences, Vol. 4, str. 155-169.

Webber, M. M. (1983) The Myth of Rationality: Development Planning Reconsidered. Environment and Planning B: Planning and Design 10, str. 89-99.

\section{GEOGRAPHICAL ASPECTS OF PROFFESIONAL PLANNING EXPERTISE}

\section{Summary}

With the analysis we can get a clear picture of situation which helps us to determine issues and goals and priorities among them. A sound analysis of existing conditions and causes also contributes to finding good solutions. And a sound fact basis will help a plan stand up to legal and political challenges to implementation.

Analysis of existing regional, spatial and other conditions help us to:

- understand facts about current and emerging conditions;

- determine goals and issues to be addressed;

- formulate general principles to guide further development;

A fact component of the analysis describes existing and projected conditions indicating the relative seriousness of problems or degree of goal attainment and factors causing or otherwise contributing to problems, goal attainment and spatial development. A value component states goals, concerns or issues, and priorities among them. A policies component describes principles to guide development, problem solving, and development management and setting priorities among issues and policies. According to this some facts are relevant to goals, other facts are relevant because they pertain to casual factors that bear on problems and some facts are relevant to the feasibility or effectiveness of potential solutions.

Without clear goals, identification of regional and spatial problem is no more than a statement of "existing conditions" without any sense of why these conditions constitute a problem. The basic general characteristic of regional and spatial problems are:

- understending problems means finding solutions for them;

- problems have no definitive formulation; 
- there are many explanations of problems;;

- the possible range of methods which can be used to solve problems is unlimited;

- there are no right or wrong solutions, they can be only good or bad, relative to one onother and the value system with which they are applied;

- there is no way of knowing when a problem has been solved. As a result they require constant monitoring, and there is always scope for improving the solution;

- it is never clear that problems are being dealt with at the proper spatial level as they have no identifiable root cause;

- once a solution of problem has been attempted it cannot be reversed;

- every problem of regional and spatial development is a unique problem. 